\title{
PENGARUH STRUKTUR KEPEMILIKAN DAN DEWAN KOMISARIS TERHADAP KINERJA BANK UMUM KONVENSIONAL YANG MENYALURKAN KREDIT PADA UMKM DENGAN PENGUNGKAPAN CORPORATE SOCIAL RESPONSIBILITY SEBAGAI MEDIASI
}

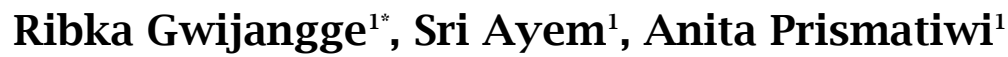 \\ ${ }^{1}$ Universitas Sarjanawiyata Tamansiswa, Jl. Kusumanegara No. 157 Yogyakarta, \\ Indonesia \\ "Korespondensi: ribkagwijangge97@gmail.com
}

\begin{abstract}
This research aims to examine the effect of institutional ownership, public ownership, board of commissioners, CSR on the performance of Conventional Commercial Banks that disburse loans to MSMEs and examine the effect of institutional ownership, public ownership, board of commissioners on CSR disclosure of Conventional Commercial Banks that disburse loans to MSMEs. This research used is associative quantitative research, the sample used is conventional banks that distribute MSME loans listed on the Indonesia Stock Exchange (IDX), using purposive sampling technique. The data used is secondary data, the data source comes from the documentation of the financial statements of conventional banks that channel MSME loans and are listed on the Indonesia Stock Exchange in 2017 2019. The data analysis technique used multiple linear regression method. The results of this research indicate that institutional ownership has no effect on bank performance. Public ownership, board of commissioners, CSR, have a positive effect on the performance of the Bank. Institutional ownership, public ownership, the board of commissioners have a positive effect on the Bank's CSR
\end{abstract}

Keywords: Institutional And Public Ownership, Board Of Commissioners, CSR, Performance Of Conventional Commercial Banks

\begin{abstract}
ABSTRAK
Penelitian ini mempunyai tujuan untuk menguji pengaruh kepemilikan institusional, kepemilikan publik, dewan komisaris, CSR terhadap kinerja Bank Umum Konvensional yang menyalurkan kredit pada UMKM dan menguji pengaruh kepemilikan institusional, kepemilikan publik, dewan komisaris terhadap pengungkapan CSR Bank Umum Konvensional yang menyalurkan kredit pada UMKM. Jenis penelitian yang digunakan adalah penelitian kuantitatif asosiatif, sampel yang digunakan adalah bank konvensional yang menyalurkan kredit UMKM terdaftar di Bursa Efek Indonesia (BEI), menggunakan teknik sampling purposive sampling. Data yang digunakan adalah data sekunder, sumber data berasal dari dokumentasi laporan keuangan bank konvensional yang menyalurkan kredit UMKM dan terdaftar di BEI tahun 2017-2019. Teknik analisis data menggunakan metode regresi linier berganda. Hasil penelitian ini menunjukkan bahwa kepemilikan institusional tidak berpengaruh terhadap kinerja Bank. Kepemilikan publik, dewan komisaris, CSR, berpengaruh positif terhadap kinerja Bank. Kepemilikan institusional, kepemilikan publik, dewan komisaris berpengaruh positif terhadap CSR Bank
\end{abstract}

Kata kunci: Kepemilikan Institusional Pan Publik, Dewan Komisaris, CSR, Kinerja Bank Umum Konvensional. 


\section{PENDAHULUAN}

Kinerja keuangan adalah alat yang digunakan untuk menggambarkan keberhasilan suatu bisnis, dengan penilailaian kinerja keuangan ini pemilik modal jadi mengetahui keadaan perusahaan yang mereka miliki sehingga mereka dapat merancang masa depan untuk bisnisnya. Kinerja keuangan sering diproksikan dengan perhitungan laba yang diperoleh perusahaan, semakin laba itu besar maka kinerja keuangan dikatakan semakin baik. Pada awal tahun 2020 pandemi covid 19 melanda dunia, menyebabkan banyak aspek usaha yang terkena dampak ini yang menyebabkan kinerja perusahaan menjadi turun drastis. Banyak bank besar mengalami penurunan kinerja keuangan yaitu dimana terjadi penurunan perolehan laba bersih akibat melorotnya margin bunga bersih. Ada nenerapa perbankan negri yang mengalami penurunan drastis laba yang diperolehnya dari tahun sebelumnya yaitu tahun 2019, seperti yang terjadi pada PT Bank Negara Indonesia Tbk (BBNI) mencatat penurunan laba sampai yakni 41\%, kemudianl Bank Tabungan Negara Tbk (BBTN) mengalami penurunan laba 40\% dari tahun lalu. Bank BRI penurunanya 36,9\%, dan Bank Mandiri penurunannya sebesar 23,9\% (Kompasonline, 2020)

Dunia perbankan mempunyai peran yang sangat penting dalam perekonomian sebuah negara dimana perbankan dapat menentukan pergerakan pertumbuhan bagi perkenomian di negara. Bank berfungsi menghimpun dana rakyat dengan tabungan kemudian menyalurkannya dalam bentuk kredit atau dalam bentuk lain yang tujuannya dalah mencapai kesejahteraan masyarakat. Keuntunga yang diperoleh perbankan merupakan keuntungan yang seharusnya tidak untuk kepentingan pemilik modal saja, namun perbankan harus memikirkan juga kepentingan masyarakat melalui kepedulian pada sosial dan lingkungan. Penerapan tata kelola perusahaan yang baik (GCG) telah menjadi salah satu indikator keberhasilan perusahaan (Ahmad et al., 2021). Keberlanjutan usaha perlu dipikirkan oleh perbankan dengan melakukan Corporate Social Responsibility (CSR) dan Good Corporate Governance (GCG). Hal ini dilakukan oleh perbankan agar mengurangi berbagai dampak negatif dalam rangka untuk membangun perusahaan yang tangguh dan sustainable (berkelanjutan). Menurut (Hendrik, 2008) Corporate Sosial Responsibility (CSR) adalah komitmen perusahan atau dunia bisnis dalam rangka melakukan pengembangan perekonomian yang berkelanjutan dengan memperhatikan pada kelestarian lingkungan dan kepedulian sosial untuk mencapai keseimbangan dunia dengan menyelaraskan aspek ekonomis, sosial, dan lingkungan.

Struktur kepemilikan perusahaan adalah komposisi kepemilikan pada perusahaan yang merupakan hal yang penting dalam mekanisme dalam corporate governance (Novitasari, T. \& Indira, 2009). Tata kelola perusahaan yang baik (Good Corporate Governance) merupakan upaya yang digunakan sebuah perusahaan melalui pengelolaan yang baik untuk meningkatkan keberhasilan usaha dan akuntabilitas perusahaan guna mewujudkan nilai pemegang saham dalam jangka panjang dengan tetap memperhatikan kepentingan stakeholder lainnya, dan nilai nilai etika. Perusahaan yang sudah mendaftarkan diri dalam bursa efek Indonesia dinamakan perusahaan yang sudag melakukan go public, dimana perusahaan seperti ini perusahaan yang dapat menjual kepemilikannya atau menjual sahamnya kepada khalayak umum atau publik, sehingga perusahaan dapat dimiliki oleh public. Kepemilikan saham publik adalah saham yang dimiliki oleh masyarakat atau publik. Melalui go public inilah perusahaan dapat didorong untuk melakukan Good Corporate Governance (GCG). Perusahaan yang sudah go public merupakan perusahaan yang kinerjanya wajib dipublikasikan sehingga publik juga berhak untuk mengawasi investasi mereka sehingga fungsi pengawasan akan lebih transparan. 
Pada Undang-undang Nomor 10 Tahun 1998 Bank Konvensional adalah bank yang melaksanakan kegiatan usaha secara konvensional yang dalam kegiatannya memberikan jasa dalam lalu lintas pembayaran. Dalam Undang-Undang hal-hal yang terkait dengan segala ketentuan dengan GCG terdapat disana, baik itu governance structure, governance process, maupun governance outcome. Governance structure mengatur kompetensi dan integritas menejemen perbankan melalui uji kelayakan dan kepatuhan terhadap pemilik, pemegang saham pengendali, dewan komisaris, direksi, dan pejabat eksekutif bank dalam aktivitas pengelolaan bank. Kedua, tntang keindependenan manajemen bank, dimana pihak manajemen bank yang terdiri dari anggota dewan komisaris dan direksi dilarang untuk mempunyai hubungan kekerabatan dan juga hubungan keuangan antara dewan komisaris dan direksi atau menjadi pemegang saham pengendali di perusahaan lain. Ketiga, penentuan dalam bidang audit dan bagaimana cara untuk meningkatkan fungsi audit bank public dimana perbankan wajib menunjuk seorang direktur yang bertanggung jawab terhadap kepatuhan regulasi yang ada.

Mengenai governance outcome, merupakan aturan yang dibuat agar perbankan melakukan pengungkapan secara transparan kinerja keuangan melalui laporan keuangan mengenai kondisi keuangan bank dan peningkatan peran auditor eksternal. Bank diwajibkan untuk mengungkapkan nonyang sudah diaudit oleh audit eksternal (LAN dan BPK, 2000). Perbankan diwajibkan untuk membuat strategi salah satunya dengan mewajibkan setiap perbankan untuk membuat rencana berupa pembuatan anggaran jangka panjang, menengang dan jangka pendek untuk mengurangi resiko-resiko pengendalian.

Usaha Mikro, Kecil, dan Menengah (UMKM) berperan penting dalam perokonomian suatu negara, dalam keadaan krisis ekonomu yang terjadi di Indonesia beberapa waktu lalu terbukti bahwa banyak usaha besar yang mengalami penurunan bahkan penutupan usaha, namun UMKM mampu menghadapi krisis tersebut dan masih terus bertahan dalam konsisi itu. Mengingat pengalaman yang ada tidak ada salahnya jika dunia perbankan memfokuskan pendanaan kearah pengembangan UMKM yang selama itu terabaikan keberadaannya karena dipandang usahanya yang masih kecil dan belum mampu bersaing dengan unit usaha lainnya (Arief et al., 2017).

Pada masa pandemik ini UMKM mengalami dampak penurunan omset sehingga untuk pembayaran kreditpun mengalami penuruan. Menurut data Bank Indonesia UMKM mengajika restrukturisasi kredit mencapai Rp1.530 triliun. Jika tidak ada langkah konkrit untuk mengatasinya, nilai ini akan bertambah sekitar 40 persen menjadi Rp2.500 triliun di akhir 2020. Kondisi pandemik ini menyebabkan nilai likuiditas untuk bank bersekala kecil mulai mengalami masalah, ditakutkan jika ga segera teratasi akan berdampak juga pada bank-bank besar (Lakadata, 2020). Berikut ini adalah tabel perkembangan kredit UMKM di Indonesia berdasarkan Indonesia Economic

Outlook 2020:

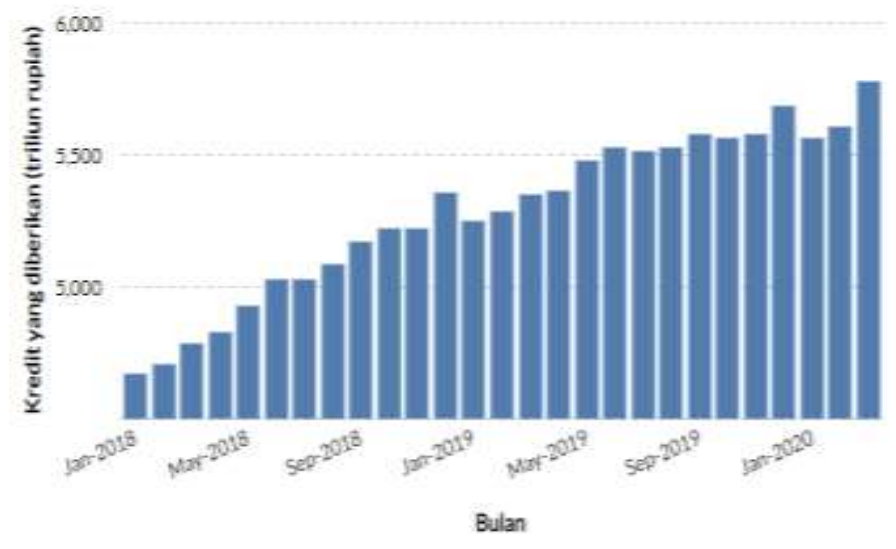




\section{Gambar 1. Perkembangan Kredit UMKM Di IndonesiaTahun 2018-2020}

Berdasarkan Gambar 1 diatas, dapat kita lihat perkembangan kredit UMKM yang ada di Indonesia dari tahun 2018 sampai 2020 mengalami kenaikan mencapai puncaknya pada tahun 2020, peningkatan ini tentunya akan dapat meningkatkan jumlah UMKM yang ada di Indonesia. Dalam situasi kenaikan kredit UMKM yang signifikan, kemudian bahwa perbankan dituntut untuk mempunyai modal kerja yang cukup untuk mendanai UMKM, maka perbankan dituntut untuk melakukan pengelolaan perusahaan secara baik. Perbankan dikelola berdasarkan prinsipprinsip GCG. Kasus yang terjadi pada PT. Bank Lippo Tbk pada tahun 2020 ditemukan pembukuan ganda oleh Bapepam, pembukuan tersebut ditemukan terdapat tiga versi laporan keuangan yang berbeda. Hal itu disebabkan bank tidak mempunyai keselarasan antara pemilik perusahaan dan manajemen, seringkali keputusan merugikan pemilik minoritas, dengan banyaknya pemilik saham minoritas otomatis kepemilikan menyebar, hal ini sering kali terdapat masalah karena semakin banyak pemilik dan makin banyak kepentingan, berbeda dengan kepemilikan yang terkonsentrasi (owner-controlled) (Bapepam, 2013).

Ukuran dewan komisaris dimana semakin banyak jumlah dewan komisaris artinya lebih banyak orang yang akan mengawasi dan memberi nasehat pada perusahaan berdampak pada proses membuat laporan keuangan yang akan lebih baik seperti penelitian Rina (2005) yang menyimpulkan bahwa semakin banyak jumlah dewan komisaris akan mampu mengurangi konflik kepentingan antara stakeholders dan mempertinggi kepercayaan investor. Kepemilikan institusional dengan semakin banyaknya pemilik perusahaan atas nama lembaga akan dapat mengurangi praktek manajemen laba, manajemen perusahaan menganggap lembaga dapat mengawasi secara ketat manajemen yang dampaknya akan mengurangi motivasi manajer untuk melakukan manajemen laba. Selain itu Investor institusional merupakan pemilik yang cermat dan cerdas, mampu menggunakan informasi saat itu untuk memprediksi keadaan keuangan masa depan dibandingkan dengan investor non institusional (Rina, 2005).

CSR adalah komitmen perusahan atau dunia bisnis dalam rangka melakukan pengembangan perekonomian yang berkelanjutan dengan memperhatikan pada kelestarian lingkungan dan kepedulian sosial untuk mencapai keseimbangan dunia dengan menyelaraskan aspek ekonomis, sosial, dan lingkungan (Azheri, 2011). Keuntungan yang diperoleh perusahaan itu juga menjadi hal masyarakat dalam bentuk tanggungjawab sosial dan lingkungan, CSR merupakan upaya untuk mencegah dampak negatif yang ditimbulkan perusahaan terhadap pihak lain dan lingkungan serta meningkatkan kualitas masyarakat termasuk karyawan, pemasok, pelanggan, dan lingkungan sekitar perusahaan. Di Indonesia terdapat UU No. 40 Tahun 2007 tentang Perseroan Terbatas (PT) pada pasal 74 Bahwa PT wajib melaksanakan tanggung jawab sosial dan lingkungan. Selain itu, kegiatan CSR juga berdasarkan Undang-undang Penanaman Modal No. 25 Tahun 2007 pasal 15(b) disebutkan bahwa setiap penanam modal berkewajiban melaksanakan tanggung jawab sosial perusahaan dan pada pasal 34 disebutkan jika tidak melaksanakan akan diberikan sangsi sanksi administratif berupa peringatan tertulis, pembatalan kegiatan usaha, pembekuan kegiatan usaha dan/atau fasilitas penanaman modal, atau pencabutaan kegiatan usaha dan/atau fasilitas penanaman modal.

Penelitian (Fua, 2007) (Sari, dan Rani, 2015) serta (Sari, et al, 2013) menunjukkan tentang kepemilikan institusional berpengaruh signifikan terhadap kinerja keuangan perusahaan. (Abdullah, 2004) menunjukkan bahwa kepemilikan saham institusional yang semakin banyak akan dapat mencegah tindakan 
perusahaan untuk melakukan tindakan yang opurtunistik. Penelitian (McConnell, J., \& Servaes, 1990) memperoleh hasil bahwa kepemilikan kepemilikan institusional berpengaruh terhadap kinerja perusahaan, dalam penelitian ini kinerja keuangan menggunakan pengukuran Tobin's Q, pengukuran ini diyakini bisa memberikan gambaran mengenai penilaian pasar terhadap perusahaan, karena Tobin's Q didapat dari nilai pasar ekuitas ditambah nilai pasar hutang dibagi dengan nilai buku aktiva. Tobin's Q memberikan gambaran tidak hanya pada aspek fundamental, tetapi juga sejauh mana pasar menilai perusahaan dari berbagai aspek yang dilihat oleh pihak luar termasuk investor.

Hasil penilitian Tona et al, 2011 diperoleh hasil terdapat pengaruh kepemilikan publik terhadap kinerja keuangan perusahaan Kepemilikan publik merupakan bentuk struktur kepemilikan yang mengikutsertakan masyarakat yang mencerminkan harapan bahwa pihak manajemen perusahan akan mengelola saham tersebut dengan sebaik-baiknya dan dibuktikan dengan tingkat laba dan kinerja perusaahn yang baik (Purba,2004). Banyaknya pemegang saham publik dan makin banyak jumlah dewan komisaris, perusahaan akan semakin banyak yang mengawasi dan berpengaruh pada kinerja keuangan perusahaan yang semakin baik. Murwaningsari (2006) menyatakan bahwa semakin banyak pengungkapan Corporate Social Responsibility akan mempengaruhi kinerja perusahan. Pengungkapan Coorporate Social Responsibility (CSR) sebagai variabel mediasi terbukti berpengaruh positif secara statistic pada hubungan return on asset dan nilai perusahan menurut (Yuniasih dan Wirakusuma, 2009).

Menurut (Sabatini \& Sudana, 2019) dalam penelitiannya menyatakan perusahaan yang banyak dimiliki oleh publik mampu memberi tekanan pada perusahaan untuk lebih melakukan pengungkapan sosial dan lingkungan. Publik menghendaki informasi yang jelas dalam laporan tahunan perusahaan suatu pengungkapan sosial dan lingkungan, maka dapat diharapkan menyadari pentingnya melakukan pengungkapan lebih banyak informasi sosial dan lingkungan. Hasil penelitian Ullman (1985) dan Cullen dan Christopher (2002) proporsi saham publik yang tinggi membuat perusahaan menjadi lebih bertanggung jawab dan ada tekanan untuk mengungkapkan lebih banyak informasi tentang CSR.

(Coller dan Gregory, 2005) dalam penelitiannya menyatakan bahwa makin banyak jumlah dewan komisaris perusahaan akan lebih mudah dikendalikan perusahaan akan menjadi lebih efektif dan mengarah kepada keberlanjutan usaha. Jika berbicara keberlanjutan usaha, perusahaan akan berfikir tentang kondisi lingkungan dan sosial. Menurut Nur (2013) jumlah dewan komisaris yang makin besar akan dapat menekan manajemen perusahaan untuk melakukan pengungkapan CSR dalam laporan tahunannya, sehingga dapat dijelaskan bahwa perusahan yang memiliki ukuran dewan komisaris yang lebih banyak akan mengungkapkan CSR lebih banyak, dengan pengungkapan CSR maka tujuan perusahan untuk mendapatkan legitimasi dari stakeholder bisa terwujud.

Penelitian ini merujuk pada penelitian sebelumnya yang dilakukan oleh Sri Ayem (2016) dengan judul Pengaruh Struktur Kepemilikan dan Dewan Komisaris terhadap Kinerja Bank Umum Konvensional yang Menyalurkan Kredit pada UMKM: Dengan Kesempatan Investasi Sebagai Variabel Mediasi. Perbedaan dengan penelitian ini terletak pada penambahan variabel yaitu yang peneliti gunakan kali ini adalah pengungkapan CSR. Berdasarkan hal ini, maka beberapa hipotesis yang diajukan sebagai berikut.

$\mathrm{H}_{1}$ : Kepemilikan institusional berpengaruh positif terhadap kinerja perusahaan.

$\mathrm{H}_{2}$ : Kepemilikan publik berpengaruh positif terhadap kinerja perusahaan.

$\mathrm{H}_{3}$ : Dewan komisaris berpengaruh positif terhadap kinerja perusahaan.

$\mathrm{H}_{4}$ : Pengungkapan CSR berpengaruh positif terhadap kinerja perusahaan.

$\mathrm{H}_{5}$ : kepemilikan institusional berpengaruh positif terhadap pengungkapan CSR 
$\mathrm{H}_{6}$ : Kepemilikan publik berpengaruh positif terhadap pengungkapan CSR.

$\mathrm{H}_{7}$ : Ukuran Dewan Komisaris berpengaruh positif terhadap Pengungkapan CSR.

\section{METODE PENELITIAN}

Dalam penilitian ini, variabel Independennya terdiri dari variabel kepemilikan institusional, kepemilikan publik, dewan direksi. Sedanagkan variabel dependennya terdiri dari variabel kinerja perusahaan (Y1) dan CSR (Y2)

Tabel 1. Definisi Operasional dan Skala Pengukuran Variabel

\begin{tabular}{|c|c|c|c|}
\hline Variabel & Definisi Operasional & Pengukuran Variabel & $\begin{array}{c}\text { Pengukuran } \\
\text { Skala }\end{array}$ \\
\hline $\begin{array}{l}\text { Kinerja } \\
\text { Perusahan (Y1) }\end{array}$ & $\begin{array}{l}\text { Kondisi perusahaan yang } \\
\text { ditunjukan dengan nilai } \\
\text { atau angka yang terdapat } \\
\text { dalam laporan } \\
\text { keuangan.Pengukuran } \\
\text { kinerja keuangan } \\
\text { menggunakan Tobin Q }\end{array}$ & $\begin{array}{l}\text { Q-Tobin = Nilai pasar } \\
\text { ekuitas + Nilai buku } \\
\text { utang Nilai Buku total } \\
\text { Ekuitas } \\
\text { (Sri Ayem, 2016) }\end{array}$ & Rasio \\
\hline $\begin{array}{l}\text { Kepemilikan } \\
\text { Institusional } \\
\text { (X1) }\end{array}$ & $\begin{array}{l}\text { Kepemilikan saham } \\
\text { perusahaan dengan } \\
\text { mengatasnamakan } \\
\text { lembaga atau institusi }\end{array}$ & $\begin{array}{l}\text { Kepemilikan } \\
\text { Institusional = dihitung } \\
\text { dengan besarnya } \\
\text { persentanse saham } \\
\text { yang dimiliki oleh } \\
\text { investor institusional } \\
\text { (Sri Ayem, 2016) }\end{array}$ & Rasio \\
\hline $\begin{array}{l}\text { Kepemilikan } \\
\text { publik (X2) }\end{array}$ & $\begin{array}{l}\text { Kepemilikan saham } \\
\text { perusahaan oleh } \\
\text { masyarakat atau kalangan } \\
\text { publik }\end{array}$ & $\begin{array}{l}\text { Kepemilikan Publik = } \\
\text { dihitung dengan } \\
\text { besarnya persentase } \\
\text { saham yang dimiliki } \\
\text { oleh public } \\
\text { (Sri Ayem, 2016) }\end{array}$ & Rasio \\
\hline $\begin{array}{l}\text { Dewan } \\
\text { Komisaris (X3) }\end{array}$ & $\begin{array}{l}\text { Jumlah dewan komisarin } \\
\text { yang ada dalam } \\
\text { perusahaan. Tugas dewan } \\
\text { komisaris adalah } \\
\text { melakukan pengawasan } \\
\text { dan nasehat kepada } \\
\text { direktur perusahaan }\end{array}$ & $\begin{array}{l}\text { Jumlah seluruh anggota } \\
\text { dewan komisaris dalam } \\
\text { suatu perusahan } \\
\text { (Sri Ayem, 2016) }\end{array}$ & Nominal \\
\hline $\begin{array}{l}\text { Pengungkapan } \\
\text { CSR (Y2) }\end{array}$ & $\begin{array}{l}\text { Indeks pengungkapan } \\
\text { tanggungjawab sosial GRI } \\
\text { G4 yang terdiri dari } 91 \\
\text { item }\end{array}$ & $\begin{array}{l}\text { Pengungkapan CSR } \\
=\text { Jumlah item CSR yang } \\
\text { diungkapkan/Jumlah } \\
\text { item CSR (91) } \\
\text { (Ivon dan Sri, 2018) }\end{array}$ & Rasio \\
\hline
\end{tabular}

Populasi penelitian ini adalah semua perusahaan perbankan yang menyalurkan kredit UMKM terdaftar di BEI tahun 2017-2019. Pemilihan sampel berdasarkan metode purposive sampling dengan kriteria sebagai berikut:

1. Perusahaan perbankan konvensional yang menerbitkan laporan keuangan berturut-turut tahun 2017-2019

2. Mata uang yang digunakan adalah Rupiah

3. Perbankan memiliki data lengkap sesuai dengan variabel yang digunakan dalam penelitian ini

Teknik Analisis Datanya sebagai berikut.

Persamaan Pertama

$\mathrm{Y} 2=\beta 0+\beta 1 \mathrm{X} 1+\beta 2 \mathrm{X} 2+\beta 3 \mathrm{X} 3+\beta 4 \mathrm{Y} 1+\varepsilon 1$

Keterangan:

Y2: Kinerja Perusahan 
X1: Kepemilikan Institusional

X2: Kepemilikan Publik

X3: Komposisi Dewan Komisaris

X4: Pengungkan CSR

$\varepsilon=$ error term

\section{Persamaan kedua}

$\mathrm{Y} 1=\beta 0+\beta 1 \mathrm{X} 1+\beta 2 \mathrm{X} 2+\beta 3 \mathrm{X} 3+\varepsilon 1$,

Keterangan:

Y1: CSR

$\mathrm{X} 1$ : Kepemilikan Institusional

X2: Kepemilikan Publik

X3: Komposisi Dewan Komisaris

$\varepsilon=$ error term

\section{HASIL DAN PEMBAHASAN}

Tabel 2. Pengujian Hipotesis Dengan Regresi Berganda Persamaan Pertama

\begin{tabular}{|c|c|c|c|c|c|c|c|}
\hline \multirow[t]{2}{*}{ Model } & \multicolumn{2}{|c|}{$\begin{array}{l}\text { Unstandardized } \\
\text { Coefficients }\end{array}$} & \multirow{2}{*}{$\begin{array}{c}\text { Standardized } \\
\text { Coefficients }\end{array}$} & \multirow[t]{2}{*}{$\mathrm{t}$} & \multirow[t]{2}{*}{ Sig. } & \multicolumn{2}{|c|}{$\begin{array}{l}\text { Collinearity } \\
\text { Statistics }\end{array}$} \\
\hline & B & $\begin{array}{l}\text { Std. } \\
\text { Error }\end{array}$ & & & & Tolerance & VIF \\
\hline (Constant) & -5.056 & 1.510 & & -3.347 & .001 & & \\
\hline $\begin{array}{l}\text { Kepemilikan } \\
\text { institusional }\end{array}$ & .005 & .015 & .022 & .313 & .755 & .858 & 1.166 \\
\hline $\begin{array}{l}\text { Kepemilikan } \\
\text { publik }\end{array}$ & .085 & .022 & .288 & 3.942 & .000 & .815 & 1.227 \\
\hline $\begin{array}{l}\text { Jumlah dewan } \\
\text { komisaris }\end{array}$ & .636 & .175 & .266 & 3.644 & .000 & .816 & 1.226 \\
\hline CSR & .256 & .050 & .380 & 5.176 & .000 & .809 & 1.235 \\
\hline
\end{tabular}

a. Dependent Variable: Kinerja Perusahaan

Dari perhitungan regresi linier berganda dengan menggunakan program SPSS for windows, maka didapat hasil sebagai berikut :

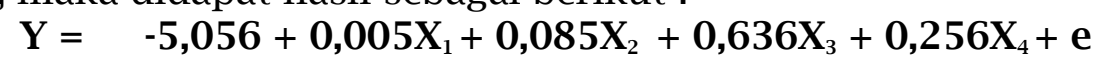

Dari persamaan tersebut di atas dapat dijelaskan :

a. Nilai $t_{\text {hitung }}$ sebesar 0,313 dan $t_{\text {tabel }}$ sebesar 1,657. Probabilitas kesalahan sebesar $0,755>0,05$. Dengan demikian $t_{\text {hitung }}$ berada pada daerah $\mathrm{H}_{0}$ diterima dan $\mathrm{H}_{\mathrm{a}}$ ditolak maka angka tersebut menunjukkan nilai yang tidak signifikan yang artinya kepemilikan institusional tidak berpengaruh terhadap kinerja Bank Umum Konvensional yang menyalurkan kredit pada Usaha Mikro Kecil Dan Menengah (UMKM) periode 2017-2019.

b. Nilai $t_{\text {hitung }}$ sebesar 3,942 dan $t_{\text {tabel }}$ sebesar 1,657. Probabilitas kesalahan sebesar $0,000<0,05$. Dengan demikian $t_{\text {hitung }}$ berada pada daerah $\mathrm{H}_{0}$ ditolak dan $\mathrm{H}_{\mathrm{a}}$ diterima maka angka tersebut menunjukkan nilai yang signifikan yang artinya kepemilikan publik berpengaruh terhadap kinerja Bank Umum Konvensional yang menyalurkan kredit pada Usaha Mikro Kecil Dan Menengah (UMKM) periode 2017-2019. Pengaruhnya positif artinya jika kepemilikan publik naik maka kinerja bank akan naik.

c. Nilai $t_{\text {hitung }}$ sebesar 3,644 dan $t_{\text {tabel }}$ sebesar 1,657. Probabilitas kesalahan sebesar $0,000<0,05$. Dengan demikian $t_{\text {hitung }}$ berada pada daerah $\mathrm{H}_{0}$ ditolak dan $\mathrm{H}_{\mathrm{a}}$ diterima maka angka tersebut menunjukkan nilai yang signifikan yang artinya jumlah dewan komisaris berpengaruh terhadap kinerja Bank Umum Konvensional yang menyalurkan kredit pada Usaha Mikro Kecil Dan Menengah 
(UMKM) periode 2017-2019. Pengaruhnya positif artinya jika jumlah dewan komisaris naik maka kinerja bank naik.

d. Nilai $t_{\text {hitung }}$ sebesar 5,176 dan $t_{\text {tabel }}$ sebesar 1,657. Probabilitas kesalahan sebesar $0,000<0,05$. Dengan demikian $t_{\text {hitung }}$ berada pada daerah $\mathrm{H}_{0}$ ditolak dan $\mathrm{H}_{\mathrm{a}}$ diterima maka angka tersebut menunjukkan nilai yang signifikan yang artinya CSR berpengaruh terhadap kinerja Bank Umum Konvensional yang menyalurkan kredit pada Usaha Mikro Kecil Dan Menengah (UMKM) periode 2017-2019. Pengaruhnya positif artinya jika pengungkapan CSR naik maka kinerja bank naik.

\begin{tabular}{lrrrrr}
\multicolumn{7}{c}{ Tabel 3. Hasil Uji Koefisien Determinasi } \\
\hline Model & R & R Square & $\begin{array}{c}\text { Adjusted R } \\
\text { Square }\end{array}$ & $\begin{array}{c}\text { Std. Error of } \\
\text { the Estimate }\end{array}$ & Durbin-Watson \\
\hline 1 & $.687^{\mathrm{a}}$ & .472 & .455 & 4.03337 & 1.846
\end{tabular}

a. Predictors: (Constant), CSR, Kepemilikan publik, Kepemilikan institusional, Jumlah dewan komisaris

b. Dependent Variable: Kinerja Perusahaan

Adjusted R square sebesar 0,455 yang menunjukkan bahwa kinerja bank dipengaruhi oleh empat variabel yaitu kepemilikan institusional, kepemilikan public, jumlah dewan komisaris, CSR sebesar 45,5\%, sisanya yaitu 54,5\% dipengaruhi variabel lain yang belum diteliti dalam penelitian ini.

Tabel 4. Pengujian Hipotesis Dengan Regresi Berganda Kedua

\begin{tabular}{|c|c|c|c|c|c|c|c|}
\hline \multirow[t]{2}{*}{ Model } & \multicolumn{2}{|c|}{$\begin{array}{l}\text { Unstandardized } \\
\text { Coefficients }\end{array}$} & \multirow{2}{*}{$\begin{array}{c}\text { Standardized } \\
\text { Coefficients } \\
\text { Beta }\end{array}$} & \multirow[t]{2}{*}{$t$} & \multirow[t]{2}{*}{ Sig. } & \multicolumn{2}{|c|}{$\begin{array}{l}\text { Collinearity } \\
\text { Statistics }\end{array}$} \\
\hline & $\mathrm{B}$ & $\begin{array}{l}\text { Std. } \\
\text { Error }\end{array}$ & & & & Tolerance & VIF \\
\hline (Constant) & 18.758 & 2.176 & & 8.620 & .000 & & \\
\hline $\begin{array}{l}\text { Kepemilikan } \\
\text { institusional }\end{array}$ & .085 & .027 & .270 & 3.190 & .002 & .929 & 1.076 \\
\hline $\begin{array}{l}\text { Kepemilikan } \\
\text { publik }\end{array}$ & .098 & .038 & .225 & 2.559 & .012 & .859 & 1.164 \\
\hline $\begin{array}{l}\text { Jumlah dewan } \\
\text { komisaris }\end{array}$ & .082 & .313 & .193 & 2.179 & .031 & .847 & 1.180 \\
\hline
\end{tabular}

a. Dependent Variable: CSR

Dari perhitungan regresi linier berganda dengan menggunakan program SPSS for windows, maka didapat hasil sebagai berikut :

$$
Y=18,758+0,085 X_{1}+0,098 X_{2}+0,682 X_{3}+e
$$

Dari persamaan tersebut diatas dapat dijelaskan :

a. Nilai $t_{\text {hitun }}<0,05$. Dengan demikian $t_{\text {hitung }}$ berada pada daerah $\mathrm{H}_{0}$ ditolak dan $\mathrm{H}_{\mathrm{a}}$ diterima maka angka tersebut menunjukkan nilai yang signifikan yang artinya kepemilikan institusional berpengaruh terhadap kinerja Bank Umum Konvensional yang menyalurkan kredit pada Usaha Mikro Kecil Dan Menengah (UMKM) periode 2017-2019. Pengaruhnya positif artinya jika kepemilikan institusional bertambah maka pengungkapan CSR juga semakin banyak.

b. Nilai $t_{\text {hitung }}$ sebesar 2,559 dan $t_{\text {tabel }}$ sebesar 1,657. Probabilitas kesalahan sebesar $0,012<0,05$. Dengan demikian $t_{\text {hitung }}$ berada pada daerah $\mathrm{H}_{0}$ ditolak dan $\mathrm{H}_{\mathrm{a}}$ diterima maka angka tersebut menunjukkan nilai yang signifikan yang artinya kepemilikan publik berpengaruh terhadap CSR Bank Umum Konvensional yang menyalurkan kredit pada Usaha Mikro Kecil Dan Menengah (UMKM) periode 2017-2019. Pengaruhnya positif artinya jika kepemilikan publik naik maka pengungkapan CSR akan naik.

c. Nilai $t_{\text {hitung }}$ sebesar 2,179 dan $t_{\text {tabel }}$ sebesar 1,657. Probabilitas kesalahan sebesar $0,031<0,05$. Dengan demikian $t_{\text {hitung }}$ berada pada daerah $\mathrm{H}_{0}$ ditolak dan $\mathrm{H}_{\mathrm{a}}$ diterima maka angka tersebut menunjukkan nilai yang signifikan yang artinya 
jumlah dewan komisaris berpengaruh terhadap CSR Bank Umum Konvensional yang menyalurkan kredit pada Usaha Mikro Kecil Dan Menengah (UMKM) periode 2017-2019. Pengaruhnya positif artinya jika jumlah dewan komisaris naik maka pengungkapan CSR akan naik.

Tabel 5. Hasil Uji Koefisien Determinasi

\begin{tabular}{lccccr}
\hline Model & R & R Square & $\begin{array}{c}\text { Adjusted R } \\
\text { Square }\end{array}$ & $\begin{array}{c}\text { Std. Error of } \\
\text { the Estimate }\end{array}$ & Durbin-Watson \\
\hline 1 & $.436^{\mathrm{a}}$ & .191 & .171 & 7.37091 & 1.552
\end{tabular}

a. Predictors: (Constant), Jumlah dewan komisaris, Kepemilikan institusional, Kepemilikan publik

b. Dependent Variable: CSR

Adjusted R square sebesar 0,455 yang menunjukkan bahwa pengungkapan CSR bank dipengaruhi oleh empat variabel yaitu kepemilikan institusional, kepemilikan public, jumlah dewan komisaris sebesar 17,1\%, sisanya yaitu 82,9\% dipengaruhi variabel lain yang belum diteliti dalam penelitian ini.

\section{Pengaruh Kepemilkan Institusional Terhadap Kinerja Bank}

Kepemilikan institusional tidak berpengaruh terhadap kinerja Bank Umum Konvensional yang menyalurkan kredit pada Usaha Mikro Kecil Dan Menengah (UMKM) periode 2017-2019.Hasil penelitian ini mendukung hasil penelitian yang dilakukan oleh Pangaribuan (2017) tidak terdapat pengaruh kepemilikan institusional terhadap kinerja. Kepemilikan lembaga mempunyai hak untuk memberikan usulan dan masukan kepada bank, untuk pengambilan keputusan keuangan perusahaan tetap berada di tangan manajemen, oleh sebab itu kepemilikan pemerintah tidak berpengaruh terhadap kinerja bank.

\section{Pengaruh Kepemilikan Publik Terhadap Kinerja Bank}

Kepemilikan publik berpengaruh positif terhadap kinerja Bank Umum Konvensional yang menyalurkan kredit pada Usaha Mikro Kecil Dan Menengah (UMKM) periode 2017-2019. Hasil penelitian ini mendukung hasil penelitian yang dilakukan oleh Sri Ayem (2016) terdapat pengaruh positif kepemilikan publik terhadap kinerja. Kepemilikan publik ini merupakan kepemilikan saham bank berasal dari masyarakat, semakin banyak kepemilikan publik akan memberikan peluang terpilihnya dewan direksi dari luar bank yang akan dapat menekan manajemen untuk memperbaiki kinerja bank.

\section{Ukuran Dewan Komisaris Terhadap Kinerja Perusahan}

Dewan komisaris berpengaruh positif terhadap kinerja Bank Umum Konvensional yang menyalurkan kredit pada Usaha Mikro Kecil Dan Menengah (UMKM) periode 2017-2019. Hasil penelitian ini mendukung hasil penelitian yang dilakukan oleh Sri Ayem (2016) terdapat pengaruh positif kepemilikan jumlah dewan komisaris terhadap kinerja. Perusahaan dengan dewan komisaris yang banyak akan semakin mempunyai kekuatan untuk memperbaiki kondisi perusahaan menjadi lebih sehat.

\section{Pengaruh Corporate Social Responsibility (CSR) dan Kinerja Perusahan}

CSR berpengaruh positif terhadap kinerja Bank Umum Konvensional yang menyalurkan kredit pada Usaha Mikro Kecil Dan Menengah (UMKM) periode 20172019. Hasil penelitian yang mendukung hasil penelitian ini adalah penelitian dari Nanik Lestari dan Novi Lelyta (2019) terdapat pengaruh positif antara CSR terhadap kinerja keuangan. Pengungkapan CSR merupakan salah satu upaya untuk 
mempertahankan keberlangsungan usaha bank, dengan pengungkapan CSR Yang banyak maka calon investor akan semakin yakin untuk menanamkan saham ke perusahaan, bank menjadi banyak pengawasnya yang mengakibatkan manajemen akan bekerja sebaik-baiknya untuk meningkatkan kinerja bank.

\section{Pengaruh Kepemilikan Institusional dan Pengungkapan Corporate Social Responsibility (CSR)}

Kepemilikan institusional berpengaruh positif terhadap pengungkapan CSR. Hasil penelitian tersebut konsisten dengan penelitian penelitian Anggraini (2006), Matoussi dan Chakroun (2008), serta Murwaningsari (2009) yang menunjukkan bahwa semakin besar kepemilikan institusional dalam suatu perusahaan maka tekanan terhadap manajemen untuk mengungkapkan tanggung jawab sosial pun akan semakin besar. Kepemilikan lembaga dapat mendorong bank untuk lebih bertanggung jawab pada lingkungan yang akhirnya akan mendapatkan keberlanjutan usaha.

\section{Pengaruh Kepemilikan Publik dan Pengungkapan corpotate social Responsibility (CSR)}

Kepemilikan publik berpengaruh positif terhadap CSR Bank Umum Konvensional yang menyalurkan kredit pada Usaha Mikro Kecil Dan Menengah (UMKM) periode 2017-201. Hasil penelitian yang mendukung hasil penelitian ini adalah penelitian dari Syailendra Eka (2017) terdapat pengaruh positif antara kepemilikan publik terhadap CSR. Kepemilikian publik akan memantau keadaan perusahaan termasuk tanggung jawab bank terhadap sosial dan lingkungan, apabila kepemilikan public semakin banyak maka bank akan mendapatkan tekanan untuk bertanggungjawab terhadap sosial dan lingkungan yang semakin besar.

\section{Pengaruh Ukuran Dewan Komisaris dan Pengungkapan CSR}

Ukuran dewan komisaris berpengaruh positif terhadap CSR Bank Umum Konvensional yang menyalurkan kredit pada Usaha Mikro Kecil Dan Menengah (UMKM) periode 2017-2019. Hasil penelitian yang mendukung hasil penelitian ini adalah penelitian dari Zulhaimi dan Nuraprianti (2019) terdapat pengaruh positif antara Ukuran dewan komisaris terhadap CSR. Dewan komisaris mempunyai andil besar berjalannya perusahaanm semakin banyak dewan komisaris maka bank akan mendapatkan banyak masukan dan pengawasan termasuk melalukan tanggung jawab sosial dan lingkungan untuk keberlanjutan bank.

\section{SIMPULAN}

Penelitian ini menyimpulkan kepemilikan institusional tidak berpengaruh terhadap kinerja perusahan Bank Umum Konvensional yang menyalurkan kredit pada Usaha Mikro Kecil Dan Menengah (UMKM) periode 2017-2019. Kepemilikan publik, dewan komisaris, CSR, berpengaruh positif terhadap kinerja Bank Umum Konvensional yang menyalurkan kredit pada Usaha Mikro Kecil Dan Menengah (UMKM) periode 2017-2019. Kepemilikan institusional, kepemilikan publik, dan ukuran dewan komisaris berpengaruh positif terhadap pengungkapan CSR. Penelitian selanjutnya diharapkan menambahkan variabel penelitian yang mempengaruhi kinerja bank dan CSR seperti arus kas, rasio hutang, struktur modal. Dengan mencoba menggunakan variabel intervening seperti Good Corporate Governance (GCG), Untuk keberlanjutan bank maka Bank yang terdaftar di BEI sebaiknya menstabilkan keuntungan (profit), manusia (people) dan lingkungan. Penelitian selanjutnya diharapkan tidak hanya mengukur pengungkapan CSR 
melalui standar saja, akan tetapi kualitas pengungkapan pula dipertimbangkan di dalamnya.

\section{DAFTAR RUJUKAN}

Abdullah, Faisal. 2004. Manajemen Perbankan. Malang: UMM Press.

Achmad Badjuri. 2012. “Analisis Faktor-Faktor Yang Mempengaruhi Kualitas Hasil Pemeriksaan Audit Sektor Publik (Studi Empiris Pada BPKP Perwakilan Jawa Tengah)." Dinamika Akuntansi, Keuangan, dan Perbankan Volume 1.

Ahmad, A., Muhammad, M., \& Narullia, D. (2021). CORPORATE RISK DISCLOSURE: THE EFFECT OF CORPORATE GOVERNANCE. JOURNAL OF APPLIED MANAGERIAL ACCOUNTING, 5(1), 101-113.

Alfredo Mahendra. 2011. "Engaruh Kinerja Keuangan Terhadap Nilai Perusahaan (Kebijakan Dividen Sebagai Variabel Moderating) Pada Perusahaan Manufaktur Di BEI." Universitas Udayana.

Anggraini, Fr. Reni Retno. 2006. "Pengungkapan Informasi Sosial Dan FaktorFaktor Yang Mempengaruhi Pengungkapan Informasi Sosial Dalam Laporan Keuangan Tahunan (Studi Empiris Pada Perusahaan-Perusahaan Yang Terdaftar Di Bursa Efek Jakarta).” Simposium Nasional Akuntansi 9.

Arief, Rival Ichsan et al. 2017. "Evaluasi Program Pemberdayaan UKM Dinas Perindustrian Dan Perdagangan Di Kota Surabaya ( Studi Di UKM Kampung Bordir Kecamatan Rungkut ) Rival Ichsan Arief." 5(April): 1-7.

Ayem, Sri, Program Studi Akuntansi, Fakultas Ekonomi, and Universitas Sarjanawiyata Tamansiswa. 2016. "PENGARUH STRUKTUR KEPEMILIKAN DAN DEWAN KOMISARIS TERHADAP KINERJA BANK UMUM KONVENSIONAL YANG MENYALURKAN KREDIT PADA UMKM : DENGAN KESEMPATAN.” 4(2).

Azheri. 2011. Corporate Social Responsibility: Dari Voluntary Menjadi Mandatory. Jakarta: : PT. Rajagrafindo.

Bapepam. 2013. No Title.

Brown and Caylor. 2004. Corporate Governance and Firm Performance.

Crisostomo, V. L., Prudencio, P. A., \& Forte, H. C. 2017. “An Analysis of The Adhere to GRI for Disclosing Information on Social Action and Sustainability Concerns." Advances in Environmental Accounting \& Management vol 6.

Daves, Bringham and. 2010. Intermediate Financial Management. South Western: Cengage Learning.

Fua, Seu'ula Johansson. 2007. "Looking towards the Source Social Justice and Leadership Conceptualisations from Tonga." Journal of Educational Administration Vol. 45 No.

Ghozali, Imam dan Chariri. 2007. Teori Akuntansi”.

Hendrik, Budi Untung. 2008. Corporate Social Responsibility.

Kompas.com. 2020. Umkm.

Kompasonline. 2020. kompasonline Kinerja Keuangan Bank.

Lakadata. 2020. No Title.

LAN dan BPK. 2000. No Title.

McConnell, J., \& Servaes, H. 1990. “Additional Evidence on Equity Ownership 
Structure, and Firm Performance." Journal of Financial Economics.

Monks R, Minow, N. 1996. Watching the Watchers: Corporate Governance for the 21 St Century. Cambridge, Blackwell.

Muh Arief Ujiyantho. 2007. "Mekanisme CSR, Manajemen Laba Dan Kinerja Keuangan.” Simposium Nasional Akuntansi X 26-28 jULI(6): 1-26.

Murwaningsari, Etty, Fakultas Ekonomi, and Universitas Trisakti. 2006. "Responsibilities Dan Corporate Financial Performance Dalam Satu Continuum." : 30-41.

Novitasari, T. \& Indira, J. 2009. "Pengaruh Struktur Kepemilikan Terhnadap Kinerja Intellectual Capital.” . Jurnal Akuntansi \& Auditing vol 5 no 2.

Rina, Mujiyanti dan. 2005. "Pengaruh Perataan Laba Pada Reaksi Pasar Di Moderasi Struktur Corporate Governance." Tesis S2 Program Pasca Sarjana UGM. Yogyakarta.

Sabatini, Kalvarina, and I Putu Sudana. 2019. "Pengaruh Pengungkapan Corporate Social Responsibility Pada Nilai Perusahaan Dengan Manajemen Laba Sebagai Variabel Moderasi.” Jurnal Ilmiah Akuntansi dan Bisnis 14(1): 56-69.

Sari, Ati Retna, Sutrisno, dan Eko Ganis Sukoharsono. 2013. "Pengaruh Kepemilikan Institusional, Komposisi Dewan Komisaris, Kinerja Perusahaan Terhadap Luas Pengungkapan Corporate Social Responsibilit." Jurnal Aplikasi Manajemen Vol. 11. N.

Wahyudi. 2006. "Implikasi Struktur Kepemilikan Terhadap Nilai Perusahaan: Dengan Keputusan Keuangan Sebagai Variabel Intervening." Simposium Nasional Akuntansi 9 Padang.

Waryanti. 2009. "Pengaruh Karakteristik Perusahaan Terhadap Pengungkapan Sosial Pada Perusahaan Manufaktur Di Bursa Efek Indonesia.” Jurnal. Semarang: Fakultas Ekonomi : UNDIP.

Wiratna Sujarweni. 2016. Panduan Mudah Menggunakan SPSS. Yogyakarta: Pustaka Baru.

Yuniasih dan Wirakusuma. 2009. "Pengaruh Kinerja Keuangan Terhadap Nilai Perusahaan Dengan Pengungkapan Corporate Social Responsibility Dan Good Corporate Governance Sebagai Variabel Pemoderasi." Jurusan Akuntansi. Fakultas Ekonomi, Universitas Udayana. 